\title{
The Effect of Nutrition Education on Body Mass Index, Waist Circumference, Mid-upper Arm Circumference and Blood Pressure in Obese Adolescents
}

\author{
Normayanti ${ }^{1 \star}$, J. B. Suparyatmo ${ }^{2}$, A. Prayitno ${ }^{1}$
}

${ }^{1}$ Postgraduate Nutrition Science Study Program, Sebelas Maret University, Surakarta, INDONESIA

${ }^{2}$ Dr. Moewardi Hospital Clinical Pathology Staff, Medical Faculty, Sebelas Maret University, Surakarta, INDONESIA

*Corresponding Author: normayanti.tamin@student,uns.ac.id

Citation: Normayanti, Suparyatmo JB, Prayitno A. The Effect of Nutrition Education on Body Mass Index, Waist Circumference, Mid-upper Arm Circumference and Blood Pressure in Obese Adolescents. Electron J Gen Med. 2020;17(5):em221. https://doi.org/10.29333/ejgm/7884

\section{ARTICLE INFO}

Received: 8 Feb. 2020

Accepted: 4 Mar. 2020

\begin{abstract}
Purpose: The aim of the study was to determine the effect of nutrition education in the form of DASH diet booklets on body mass index, waist circumference, mid-upper arm circumference, and blood pressure in obese adolescents.

Methods: This study was quasi-experimental, which is pre-test and post-test with control group design. The number of subjects was 60 respondents. The groups in this study were divided into two; one treatment group and one control group. The first group was given a nutrition education intervention with a booklet and the second group was not treated. Data analysis used paired t-test and independent $t$-test $(\mathrm{p}=0.05 ; \mathrm{Cl}=95 \%)$, Wilcoxon test, Mann-Whitney test, and Spearman rank test.

Results: There were differences in BMI, waist circumference, mid-upper arm circumference, and significant systolic blood pressure in the treatment group after the intervention. The mean average of the treatment group decreased significantly; BMI: $0.36 \pm 0.05 \mathrm{~kg} / \mathrm{m2}$; waist circumference: $0.84 \pm 0.14 \mathrm{~cm}$; mid-upper arm circumference: $0.37 \pm 0.63 \mathrm{~cm}$, and systolic blood pressure: $1.13 \pm 1.36 \mathrm{mmHg}$. In the control group the average BMI, waist circumference, mid-upper arm circumference, and systolic blood pressure were increased significantly. The treatment group experienced a decrease in energy intake by $524.65 \pm 85.77 \mathrm{kcal}$ while physical activity increased by $0.635 \pm 0.09$. Conversely, the control group experienced an increase in energy intake by $147.29 \pm 25.18 \mathrm{kcal}$, while physical activity decreased by $0.470 \pm 0.08$. Changes in energy intake and physical activity between the treatment group and the control group were identified as significant correlations $(p<0.001)$. Similar to it, the changes in the $\mathrm{BMI}$, waist circumference, mid-upper arm circumference, and significant systolic blood pressure were identified as significant correlations $(p<0.001)$.
\end{abstract}

Application: The use of booklets can be a solution for the continuation of effective nutrition education as the nutritional information becomes easier to be comprehended and adapted by the booklet recipients and used in everyday life.

Keywords: nutrition education, obese, adolescent, BMI, waist circumference, MUAC

\section{INTRODUCTION}

Obesity is a complex and multifactorial disease that can be prevented (1), often associated with an increased risk of various chronic diseases such as type 2 diabetes (T2D), hypertension, and cardiovascular disease (CVD) (2). The increasing trend of obesity that occurs in most developed countries has begun to stabilize, but the incidence of morbid obesity in developing countries has continued to increase, including obesity originating from among children and adolescents (3).

Globally, 170 million children (aged $<18$ years) are estimated to be overweight and obese (4). The highest increase in the prevalence of obesity in children occurs in low and middle-income countries, with an increased rate of up to $30 \%$ higher than in developed countries (5). In Indonesia, an increase in the prevalence of adolescents who are overweight can be observed in the range of 2010 to 2018 . The prevalence of fat in adolescents aged 13-15 years increased from $2.5 \%$ (2010) to $10.8 \%$ (2013) and $16 \%$ (2018) consisting of; $11.2 \%$ overweight and $4.8 \%$ are obese, while the prevalence of fat in adolescents aged 16-18 years also increased from 1, 4\% (2010) to $7,3 \%(2013)$ and $13.5 \%$ (2018) consisting of; $9.5 \%$ are overweight and $4 \%$ are obese (6-8). Central Java Province is one of the provinces that experienced an increase in the obesity prevalence of adolescents aged $16-18$ years from $1.7 \%$ (2010) to $3.7 \%$ (2018), and very close to the national prevalence of $4 \%$ (2018). The obesity tends to be more experienced by adolescent girls by $4.5 \%$, while in adolescent boys by $3.6 \%$ $(7,8)$.

Adolescents tend to develop unhealthy eating habits and consume foods with unbalanced nutrients so that they are vulnerable to gain weight that exceeds the threshold and even 
reaches the obesity category based on BMI/U index (9). The effects of fatness (overweight) in adolescence can be: (1) continue to become obese as an adult $(10,11) ;(2)$ increase the risk of degenerative diseases, such as type 2 diabetes mellitus, cardiovascular disease, chronic kidney disease, and cancer (12); and (3) increase mortality and early death (13).

Research shows that hypertension in children and adolescents is related to a higher body weight (overweight or obese) (14). Children and adolescents generally have blood pressure less than $120 / 80 \mathrm{mmHg}$; a measurement that is considered normal in adults but can indicate hypertension problems in children and adolescents depending on age, sex, and height. Teenagers are eight times more likely to experience an increase in blood pressure that is not screened so that it is not detected. It indicates the need for better blood pressure monitoring in children and adolescents to prevent long-term complications resulting from hypertension $(15,16)$. In addition to cardiovascular disease, obesity is also known to have relevance to public health, so it requires effective prevention strategies to overcome obesity early on, one of which can be done through increasing adolescent awareness about the importance of nutritional balance (17).

Nutrition education is conducted to convey the importance of fulfilling balanced nutritional needs for teenagers (18) and as an effort to achieve balanced nutrition so identifying the optimal diet can be applied to prevent the disease progression, especially chronic disease that becomes an element of the public health effort priority. There has been no effective diet recommended for obese adolescents nowadays; the handling of nutrition is only limited to a balanced eating recommendation with increased physical activity but has not provided recommended applied dietary pattern yet $(19,20)$. Provide recommendations for an applied diet is one of the ways to impart the knowledge and to enhance nutritional awareness of adolescents so that from an early age they can comprehend the importance of maintaining health through balanced nutrition while at the same time they start to adopt a healthier eating pattern.

Dietary Approaches to Stop Hypertension (DASH) is an applied dietary pattern that was originally initiated to prevent hypertension but later in its development it was recommended to be one of the ideal diets for adults (21) and teenagers (ages 11-17) (22). The DASH diet is indicated to provide potential benefits to prevent the development of diabetes mellitus and the metabolic syndrome (23) because it is a diet that has high intake in the whole grains, fruits, vegetables, low-fat dairy products combined with limited consumption of saturated fat sources, red meats, sweet foods, and drinks that contain sugar. The DASH diet pattern, which is high in fiber, antioxidants, unsaturated fats, and the use of low-fat dairy products, can support to prevent an increase of blood pressure and increase the insulin homeostasis and glucose tolerance (24).

The use of booklets as an educational media has been recommended as an effort to provide health information for adolescents related to obesity (25). Research on adolescents using media booklets provides an influence in enhancing health knowledge in adolescents who are overweight and obese (26). The research has not yet concluded whether health education with booklet media is appropriate and effective as a solution in overcoming nutritional problems associated with changes in adolescent eating behavior that has an impact on changes in body dimensions of obese adolescents. Therefore, researchers are interested in conducting research aiming at determining the effect of nutrition education through the DASH diet booklet on body mass index (BMI), waist circumference, mid-upper arm circumference (MUAC), and blood pressure of obese adolescents in the Surakarta State High School.

\section{MATERIAL AND METHOD}

This study is analytical research with quasi-experimental pretest-posttest control group design. The study was conducted in August - November 2019 in six Surakarta State High Schools, i.e., SMA Negeri 2, SMA Negeri 3, SMA Negeri 4, SMA Negeri 5, SMA Negeri 7, and SMA Negeri 8. The population in this study were all adolescent girls 14-17 years that fit the inclusion criteria. The sample size calculation used open epi application and obtained a minimum sample of 27 subjects added by $10 \%$ drop out so that what is needed in each group is 30 people. The subject selection of this study used a purposive sampling method, and it was obtained 60 people divided into two groups: the treatment group and control groups. Subjects who followed this study to completion were 30 people in treatment groups, and 30 people control groups. The inclusion criteria in this study were adolescent girls who were categorized as obese based on the results of the BMI calculation at $\geq$ the 95 th percentile (or $\geq 26.3 \mathrm{~kg} / \mathrm{m} 2$ ) of 2007 WHO anthropometric standards, and residing in the Surakarta City area. Subjects were excluded from the study if the subject was undergoing specific dietary therapies in the treatment of the disease, and the subjects were remaining from severe infectious diseases in the last 3 (three) months. Meanwhile, the subject's criteria stated to be dropped out if they resign during the study.

Both in the treatment group and control groups, pre-test for measurements of body mass index (BMI), waist circumference, mid-upper arm circumference (MUAC), and blood pressure were conducted. The treatment group was treated with booklet of nutrition education, which would be accompanied by an explanation of the contents of the booklet for \pm 20 minutes (frequency once a week was given for four weeks). A month after subjects in the treatment group received booklet of nutrition education for four weeks, the research data was taken in the form of post-test measurements including body mass index (BMI) data, waist circumference, mid-upper arm circumference (MUAC) and blood pressure on treatment group and control groups that were conducted.

Three kind of research variables were conducted in this study; the independent variable, the dependent variable, and the intermediate variable. The independent variable in this study is nutrition education through booklet, then the dependent variables are body mass index, waist circumference, upper-arm circumference, and blood pressure and the intermediate variables are energy intake and physical activity. The contents of the booklet were made by researchers from the modification of the booklet material about the Dietary Approaches to Stop Hypertension (DASH) diet developed by the National Heart, Lung, and Blood Institute (27). The booklet encompasses the definition of obesity and how to calculate BMI, causes of obesity, the impact of obesity, how to prevent obesity, an explanation of unhealthy eating patterns, and how to overcome obesity by applying a healthy diet (DASH diet). The booklet was given at the beginning after pre-test data was taken on the subject of treatment. At the same time, nutrition education contents in the booklet were explained to the 
Table 1. Characteristics of the study subjects before the study $(n=60)$

\begin{tabular}{|c|c|c|c|c|c|c|c|}
\hline \multirow{2}{*}{ Characteristics of the subject } & \multicolumn{3}{|c|}{ Treatment $(n=30)$} & \multicolumn{3}{|c|}{ Control $(n=30)$} & \multirow{2}{*}{$\mathbf{P}^{c}$} \\
\hline & Min & Max & Mean \pm SD & Min & Max & Mean \pm SD & \\
\hline Age (year) & 15 & 17 & $15.93 \pm 0.58$ & 14 & 17 & $15.83 \pm 0.59$ & 0.81 \\
\hline Body weight (kg) & 64.5 & 89.5 & $75.83 \pm 6.86$ & 65.9 & 87.0 & $74.70 \pm 5.47$ & 0.12 \\
\hline Body height $(\mathrm{cm})$ & 149.0 & 169.0 & $157.08 \pm 4.92$ & 147.3 & 165.0 & $156.38 \pm 5.01$ & 0.93 \\
\hline $\mathrm{BMI}^{\mathrm{a}}\left(\mathrm{kg} / \mathrm{m}^{2}\right)$ & 28.16 & 34.54 & $30.68 \pm 1.50$ & 28.06 & 34.53 & $30.54 \pm 1.60$ & 0.92 \\
\hline Waist circumference $(\mathrm{cm})$ & 78.5 & 107.0 & $89.63 \pm 7.68$ & 81.0 & 107.1 & $89.55 \pm 6.00$ & 0.10 \\
\hline $\operatorname{MUAC}^{\mathrm{b}}(\mathrm{cm})$ & 27.0 & 38.0 & $32.18 \pm 3.03$ & 27.2 & 36.5 & $31.55 \pm 2.29$ & 0.09 \\
\hline Systolic blood pressure (mmHg) & 102 & 120 & $113.67 \pm 5.15$ & 100 & 120 & $112.40 \pm 5.81$ & 0.74 \\
\hline Diastolic blood pressure (mmHg) & 60 & 80 & $72.40 \pm 5.26$ & 60 & 80 & $72.80 \pm 5.96$ & 0.43 \\
\hline Energy intake (kcal) & 2230.10 & 3312.00 & $2736.89 \pm 313.54$ & 2222.50 & 3120.90 & $2719.79 \pm 245.48$ & 0.10 \\
\hline Physical activity & 1.170 & 2.840 & $2.080 \pm 0.46$ & 1.161 & 3.275 & $2.268 \pm 0.53$ & 0.77 \\
\hline
\end{tabular}

${ }^{\mathrm{a} B M I}=$ Body Mass Index; ${ }^{\mathrm{b}}$ Mid-upper arm circumference ; ${ }^{\mathrm{C}}$ Independent $\mathrm{t}$-test

subject so they aimed to understand the contents of the booklet better.

The BMI variable was measured using a scale (weight) and microtoise (height), the waist circumference variable was measured using a measuring tape, the mid-upper arm circumference variable was measured using a MUAC band, and the blood pressure variable was measured using a calibrated mercury sphygmomanometer. Energy intake data were collected by doing $3 \times 24$ hours of food-recall, which was conducted six times randomly in 4 school days and two days off. While physical activity variables were measured using the Physical Activity Questionnaire for Adolescents (PAQ-A) developed by Kowalski et al. (28) and have been modified into Indonesian.

Data analysis was performed by paired t-test to observe the changes in pre-test and post-test in the treatment and control groups, then independent t-test to observe differences in the treatment and control groups. Besides, a correlation test was also conducted to perceive the relationship of changes in energy intake and physical activity to changes in body mass index (BMI), waist circumference, mid-upper arm circumference (MUAC), and obese adolescent blood pressure. Research ethics with informed consent, anonymity, confidentiality.

\section{Ethical Clearance}

Ethical clearance was obtained from the Research Ethics Commission of Sebelas Maret University, Surakarta, No. 143/UN27.06/KEPK/2019.

\section{RESULTS}

\section{Characteristics of Research Subjects}

Homogeneity test results of the research variables in Table 1 indicate that the characteristics of the subjects in the treatment group and the control group are homogeneous or the same $(p>0.05)$. The research group has fulfilled the requirements of experimental research, which is each research group before the research must be equal or comparable.

\section{The Effects of Nutrition Education on BMI, Waist Circumference, Mid-upper Arm Circumference, and Blood Pressure}

The results of the paired t-test analysis in Table 2 demonstrate that the mean BMI, waist circumference, midupper arm circumference, and systolic blood pressure in the
Table 2. Changes in BMI, waist circumference, mid-upper arm circumference and blood pressure before and after the intervention in the treatment and control groups

\begin{tabular}{|c|c|c|c|}
\hline Variable & Before & After & $\mathbf{P}$ \\
\hline \multicolumn{4}{|c|}{ Treatment group } \\
\hline$B M I^{\mathrm{a}}\left(\mathrm{kg} / \mathrm{m}^{2}\right)$ & $30.68 \pm 1.50$ & $30.31 \pm 1.50$ & $<0.001$ \\
\hline Waist circumference $(\mathrm{cm})$ & $89.63 \pm 7.68$ & $88.79 \pm 7.69$ & $<0.001$ \\
\hline $\mathrm{MUAC}^{\mathrm{b}}(\mathrm{cm})$ & $32.18 \pm 3.03$ & $31.76 \pm 3.32$ & $0.004^{\circ}$ \\
\hline Systolic blood pressure (mmHg) & $113.67 \pm 5.15$ & $112.53 \pm 5.11$ & $<0.001$ \\
\hline Diastolic blood pressure $(\mathrm{mmHg})$ & $72.40 \pm 5.26$ & $72.7 \pm 6.37$ & $0.974^{\mathrm{C}}$ \\
\hline \multicolumn{4}{|c|}{ Control group } \\
\hline$B M I^{a}\left(k g / m^{2}\right)$ & $30.54 \pm 1.60$ & $30.83 \pm 1.51$ & $<0.001$ \\
\hline Waist circumference $(\mathrm{cm})$ & $89.55 \pm 6.00$ & $90.29 \pm 6.16$ & $<0.001$ \\
\hline $\operatorname{MUAC}^{\mathrm{b}}(\mathrm{cm})$ & $31.55 \pm 2.29$ & $32.01 \pm 2.30$ & $<0.001$ \\
\hline
\end{tabular}

\begin{tabular}{lllll}
\hline Systolic blood pressure $(\mathrm{mmHg})$ & $112.40 \pm 5.81$ & $112.93 \pm 5.86$ & $0.107^{\mathrm{d}}$ \\
\hline
\end{tabular} \begin{tabular}{lllll}
\hline Diastolic blood pressure $(\mathrm{mmHg})$ & $72.80 \pm 5.96$ & $73.13 \pm 7.40$ & $0.455^{\mathrm{d}}$
\end{tabular} ${ }^{\mathrm{a} B M I}=$ Body Mass Index; ${ }^{\mathrm{b}}$ Mid-upper arm circumference; cPaired t-test; dWilcoxon test

Table 3. Changes in BMI, waist circumference, MUAC and blood pressure between the treatment and control groups

\begin{tabular}{cccc}
\hline \multirow{2}{*}{ Variable } & \multicolumn{2}{c}{ Change } & \multirow{2}{*}{$\mathbf{P}$} \\
\cline { 2 - 4 } & Treatment & Control & \\
\hline BMI $^{\mathrm{a}}\left(\mathrm{kg} / \mathrm{m}^{2}\right)$ & $-0.36 \pm 0.05$ & $0.29 \pm 0.05$ & $<0.001^{\mathrm{c}}$ \\
\hline Waist circumference $(\mathrm{cm})$ & $-0.84 \pm 0.14$ & $0.75 \pm 0.30$ & $<0.001^{\mathrm{c}}$ \\
\hline MUAC $^{\mathrm{b}}(\mathrm{cm})$ & $-0.37 \pm 0.63$ & $0.47 \pm 0.07$ & $<0.001^{\mathrm{c}}$ \\
\hline Systolic blood pressure $(\mathrm{mmHg})$ & $-1.13 \pm 1.36$ & $0.53 \pm 1.81$ & $<0.001^{\mathrm{d}}$ \\
\hline Diastolic blood pressure $(\mathrm{mmHg})$ & $-0.13 \pm 3.06$ & $0.33 \pm 3.02$ & $0.948^{\mathrm{d}}$ \\
\hline${ }^{\mathrm{a} B M I}=$ Body Mass Index; ${ }^{\mathrm{b} M i d-u p p e r}$ arm circumference; clndependent \\
$t$-test; d Mann-Whitney test & & &
\end{tabular}

treatment group experienced a significant decrease $(p<0.001)$ after nutrition education intervention was given through a booklet. Conversely, in the control group of mean BMI, waist circumference, mid-upper arm circumference, and systolic blood pressure experienced a significant increase $(p<0.001)$.

Table 3 illustrates a significant decrease in BMI, waist circumference, MUAC and systolic blood pressure in the treatment group with a mean reduction in BMI of $0.36 \pm 0.05$ $\mathrm{kg} / \mathrm{m}^{2}$, while a decrease in waist circumference of $0.84 \pm 0.14 \mathrm{~cm}$, a decrease in MUAC of $0.37 \pm 0.63 \mathrm{~cm}$ and a decrease in systolic blood pressure of $1.13 \pm 1.36 \mathrm{mmHg}$. Conversely, in the control group, there were increases in BMI, waist circumference, MUAC, and blood pressure. Changes in BMI, waist circumference, MUAC, and systolic blood pressure between the treatment and control groups were identified as significant $(p<0.001)$. 
Table 4. Changes in energy intake and physical activity before and after the intervention in the treatment and control groups

\begin{tabular}{cccc}
\hline Variable & Before & After & p \\
\hline Treatment group & & & \\
\hline Energy intake (kcal) & $2736.89 \pm 313.54$ & $2212.24 \pm 312.15$ & $<0.001^{\mathrm{a}}$ \\
\hline Physical activity & $2.080 \pm 0.46$ & $2.715 \pm 0.47$ & $<0.001^{\mathrm{a}}$ \\
\hline Control group & & & \\
\hline Energy intake (kcal) & $2719.79 \pm 245.48$ & $2867.08 \pm 249.71$ & $<0.001^{\mathrm{a}}$ \\
\hline Physical activity & $2.268 \pm 0.53$ & $1.797 \pm 0.56$ & $<0.001^{\mathrm{a}}$ \\
\hline
\end{tabular}

a paired t- test

Table 5. Differences in energy intake and physical activity after the intervention in the treatment and control groups

\begin{tabular}{ccccc}
\hline \multicolumn{1}{c}{ Variable } & Treatment & Control & p \\
\hline Energy intake (kcal) & $-524.65 \pm 85.77$ & $147.29 \pm 25.18$ & $<0.001^{\text {a }}$ \\
\hline Physical Activity & $0.635 \pm 0.09$ & $-0.470 \pm 0.08$ & $<0.001^{\text {a }}$ \\
\hline${ }^{\text {a Independent } \text {-test }}$ & & &
\end{tabular}

\section{The Differences in Energy Intake and Physical Activity}

Table 4 demonstrates a decrease in energy intake and an increase in physical activity in the treatment group. Meanwhile, in the control group, there was an increase in energy intake and decrease physical activity. Energy intake in the treatment group after the intervention had a mean of $2212.24 \pm 312.15 \mathrm{kcal}$ which decreased from the mean before the intervention $2736.89 \pm 313.54 \mathrm{kcal}$ while in the control group had a mean of $2867.08 \pm 249.71 \mathrm{kcal}$ which increased from the initial mean of $2719.79 \pm 245.48 \mathrm{kcal}$. Physical activity in the treatment group had a mean of $2.715 \pm 0.47$ which increased from the mean before intervention $2.080 \pm 0.46$ while the control group had a mean of $1.797 \pm 0.56$ which decreased from the initial mean of $2.268 \pm 0.53$. Changes in energy intake and physical activity in the treatment and control groups had significant identified differences $(p<0.001)$.

Table 5 illustrates a significant decrease in energy intake and a significant increase in physical activity in the treatment group with a mean decrease in energy intake by $524.65 \pm 85.77$ $\mathrm{kcal}$, and an increase in physical activity by $0.635 \pm 0.09$. Conversely, in the control group, there was an increase in energy intake by $147.29 \pm 25.18 \mathrm{kcal}$, and a decrease in physical activity by $0.470 \pm 0.08$. Changes in energy intake and physical activity between the treatment group and the control group were identified as significant $(p<0.001)$.

The Relationship of Energy Intake and Physical Activity to BMI, Waist Circumference, MUAC, and Blood Pressure

The analysis results in Table 6 indicate the relationship between changes in energy intake and changes of; BMI, waist circumference, MUAC, and blood pressure of obese adolescents. Changes in energy intake and BMI demonstrated a very strong relationship $(r=0.95)$ and were statistically significant $(p<0.001)$. Changes in energy intake with waist circumference showed a very strong relationship $(r=0.94)$, which was statistically significant $(p<0.001)$. Changes in energy intake with MUAC illustrate a strong relationship $(r=0.79)$, which was statistically significant $(p<0.001)$. Changes in energy intake with systolic blood pressure revealed an association with moderate correlation strength $(r=0.59)$, which was statistically significant $(p<0.001)$. When it was viewed from the direction of the relationship, the correlation has a positive relationship, that is, if there a change in the form of an increase in energy intake, BMI, waist circumference, MUAC, and systolic
Table 6. Correlation of changes in energy intake and physical activity with BMI, waist circumference, MUAC, and systolic blood pressure after the intervention

\begin{tabular}{cccc}
\hline $\begin{array}{c}\text { Dependent } \\
\text { Variable }\end{array}$ & Independent Variable & r & p \\
\hline Energy intake $(\mathrm{kcal})$ & $\mathrm{BMI}^{\mathrm{a}}\left(\mathrm{kg} / \mathrm{m}^{2}\right)$ & 0.95 & $<0.001^{\mathrm{c}}$ \\
\hline & Waist circumference $(\mathrm{cm})$ & 0.94 & $<0.001^{\mathrm{c}}$ \\
\hline $\mathrm{MUAC}^{\mathrm{b}}(\mathrm{cm})$ & 0.79 & $<0.001^{\mathrm{c}}$ \\
\hline & Systolic blood pressure $(\mathrm{mmHg})$ & 0.59 & $<0.001^{\mathrm{c}}$ \\
\hline & Diastolic blood pressure $(\mathrm{mmHg})$ & -0.39 & $0.05^{\mathrm{c}}$ \\
\hline Bhysical Activity & $\mathrm{BMI}^{\mathrm{a}}\left(\mathrm{kg} / \mathrm{m}^{2}\right)$ & -0.88 & $<0.001^{\mathrm{c}}$ \\
\hline & Waist circumference $(\mathrm{cm})$ & -0.88 & $<0.001^{\mathrm{c}}$ \\
\hline MUAC $(\mathrm{cm})$ & -0.79 & $<0.001^{\mathrm{c}}$ \\
\hline & Systolic blood pressure $(\mathrm{mmHg})$ & -0.55 & $<0.001^{\mathrm{c}}$ \\
\hline & Diastolic blood pressure $(\mathrm{mmHg})$ & 0.001 & $0.99^{\mathrm{c}}$ \\
\hline aBMl: Body Mass & Index; ${ }^{\mathrm{b} M i d-u p p e r}$ arm Circumferenc; & $\mathrm{c}$ & Rank
\end{tabular}
Spearman test

blood pressure will increase. Changes in physical activity and $\mathrm{BMI}$ in this study also had a very strong correlation ( $r=-0.88)$ and significant $(p<0.001)$. Changes in physical activity with waist circumference indicated a very strong relationship ( $r=-0.88)$, which was statistically significant $(p<0.001)$. Changes in physical activity with MUAC showed a strong relationship ( $r=-$ $0.79)$, which was statistically significant $(p<0.001)$. Changes in physical activity with systolic blood pressure showed an association with moderate correlation strength $(r=-0.55)$, which was statistically significant $(p<0.001)$. This correlation revealed the direction of a negative relationship; if there is a change in the form of decreased physical activity, then BMI, waist circumference, MUAC, and systolic blood pressure will increase, and vice versa. Based on the correlation analysis, it can be concluded that in this study, there is a significant relationship between changes in energy intake and physical activity and on the changes of; BMI, waist circumference, MUAC, and systolic blood pressure in obese adolescents.

\section{DISCUSSIONS}

Dietary Approaches to Stop Hypertension (DASH) is an applied dietary pattern that was initially more often recommended as an ideal diet for adults but has not been widely applied to adolescents. This experimental study is the first to assess the implications of providing nutrition education with a booklet containing a recommended DASH dietary pattern for obese adolescents. This research is important because it assesses the benefits and accommodates the DASH diet as a recommended dietary pattern for adolescents and to analyze the effects of the DASH diet pattern on Body Mass Index (BMI), waist circumference, mid-upper arm circumference and blood pressure in obese adolescents.

\section{The Effect of Nutrition Education on Body Mass Index}

The results of the study in the treatment group and the control group revealed that the mean BMI in each group experienced changes after the intervention was given. In the treatment group, the mean BMI experienced a decrease whereas in the control group the BMI mean experienced an increase. The mean before and after in the treatment and control groups had significant differences $(p<0.001)$. The results of this study support previous research in Iran by Mazloomy-Mahmoodabad et al. (29), which stated health 
education interventions for six weeks can reduce the BMI of obese adolescents up to $0.46 \pm 0.78 \mathrm{~kg} / \mathrm{m}^{2}$.

The provision of nutrition booklets has an effect on the reduction of adolescent $\mathrm{BMI}$ with a significant mean difference, this result was different from the study did by Lanita et al. (26) who reported that the reduction in mean BMI in the booklet group was statistically insignificant $(p>0.05)$. This might be due to the frequency of giving a booklet which was once only so it did not give maximum effect and the booklet giving was not completed with explanation of the contents of the booklet. Teenagers would better understand the contents of the booklet when it is given along with an explanation of its contents. Further, the provision of material related to the contents of the booklet needs to be done by nutritionists who are competent in their fields. It is in line with research (30), which stated that nutrition professionals are identified as the most suitable for giving advice related to weight management in obese people.

\section{The Effect of Nutrition Education on Waist Circumference}

Waist circumference is one of the ways to measure visceral adipose tissue, which is often associated with metabolic disorders in children and adolescents (31) and even considered to be more effective in terms of predicting adiposity and insulin resistance (32). The results of the study in the treatment group and the control group showed a change in waist circumference. After the intervention was given, the mean waist circumference group decreased while in the control group, the mean waist circumference increased. The mean waist circumference before and after the treatment and control groups had significant differences. The research did by Motlagh et al. (33) on Iranian adolescents reported waist circumference measurements were used to identify obesity, and the decline could indicate improved health. Increased waist circumference in adolescents is important to prevent, so it will not cause adverse health effects in the future (34).

Nutrition education through the media booklet imparts an influence on waist circumference because it can help prevent an increase or even decrease the waist circumference of obese adolescents. The changes of waist circumference are possible because there were changes in dietary patterns as it initiates awareness about health hazards and the importance of changing unhealthy dietary patterns, especially because eating habits learned during childhood and adolescence tend to continue into adulthood (35).

\section{The Effect of Nutrition Education on Mid-upper Arm Circumference (MUAC)}

The results in the treatment group and the control group indicated that the mean of mid-upper arm circumference (MUAC) in each group experienced a change after given intervention as; in the treatment group, the mean MUAC decreased while in the control group, the mean MUAC increased. The mean before and after intervention in the treatment and control groups had significant differences. Nutrition education through booklets was possible to influence the changes in arm circumference for obese adolescents. Those results support the research did by Dharmade and Kale (36) in India of the influence of nutrition education on anthropometric measurements of adolescent girls. Their research results revealed that exposure to nutrition education had brought positive changes in anthropometric measurements of adolescent girls as it makes the MUAC of adolescents change towards the normal range. The importance of preventing an increase in arm circumference began to be noted after studies linked MUAC measures with more functional outcomes, namely the development of comorbidities associated with obesity such as type 2 diabetes and cardiovascular disease and the presence of risk factors for the disease (37).

\section{The Effects of Nutrition Education on Blood Pressure}

The results of the study in the treatment group and the control group showed a mean change in systolic blood pressure. The mean systolic blood pressure in each group experienced changes after being given an intervention as; in the treatment group, the mean systolic blood pressure decreased, while in the control group, the systolic blood pressure increased. The mean before and after intervention in the treatment group and control groups had significant differences $(p<0.001)$. Nutrition education through booklets imparts an influence on the systolic blood pressure of obese adolescents, possibly due to a decrease in BMI, which is also an indication of weight loss in adolescents. Weight loss with blood pressure control had been shown to be related in clinical studies, and weight loss is even first-line therapy in obese adolescents with hypertension (15).

Obesity has been considered as one of the causes of hypertension. It is widely recognized that overweight and obesity closely related to the occurrence of hypertension in children and adolescents (38). Blood pressure increase in obesity conditions is often associated with activity increase of the central nervous system. In obese individuals, the most likely thing to happen is baroreflex inhibition (the body's homeostatic mechanism that helps maintain blood pressure at almost constant levels) $(39,40)$. The fact that obesity and hypertension can occur independently and together shows that both of them may be a sign of something that is metabolically wrong, and therefore they may be effects. Further, obese adolescents tend to have food consumption that exceeds daily calorie needs. Unfortunately, it becomes a habit for eating the foods which contain high calorie and fat. These foods are also often associated with high sodium intake and have an impact on increasing blood pressure (especially systolic blood pressure) in children and adolescents (41). The epidemic of obesity and hypertension has emerged along with significant changes in the consumption of fast food and instant foods which are high in sodium, trans fat, and fructose corn syrup accompanied by decreased physical activity due to automation of activities that previously required more physical work (42).

\section{The Relationship of Energy Intake and Physical Activity to Adolescent Obesity}

The results of the study indicated a decrease in energy intake and a significant increase in physical activity for the treatment group. Conversely, in the control group, there was an increase in energy intake and decreased physical activity. Changes in energy intake and physical activity between the treatment group and the control group were identified as significant $(p<0.001)$. Nutrition education is assumed to influence energy intake and physical activity because if there is a change in BMI, waist circumference, MUAC, and systolic blood pressure in obese adolescents will change the nutritional intake and physical activity. This change is associated with nutrition education that was conducted. It can be caused by 
changes in dietary patterns in obese adolescents related to the awareness of adolescents to start maintaining food (the amount and type) and ultimately have an impact on reducing energy intake.

Nutrition education is an effort to convey information for adolescents. Those who get it will have a higher chance to follow the recommendations in the booklet. Changes in energy intake and BMI, waist circumference, MUAC, and systolic blood pressure in the study were correlated. As seen from the direction of the relationship, the correlation has a positive relationship; that mean, if there is a change in the form of an increase in energy intake, other variables will experience an increase. Nutrition education through booklets in the research can help obese adolescents to be able to change their excessive daily energy intake to become more balance as needed gradually (43). Apart from it, changes was occurred in the physical activity of obese adolescents who have increased in line with the decrease in energy intake. This shows that nutrition education not only has a good impact through changes in dietary patterns and nutrition intake of adolescent obese who have become more balance but also through increase of the physical activity.

\section{CONCLUSION}

In conclusion, there were correlation of physical activity with BMI, waist circumference, MUAC, and systolic blood pressure indicates the direction of a negative relationship. That statement is in line with research, which states that as physical activity decrease, body dimensions will increase. But it is not only the physical activity important to consider but also the nutrition intake of adolescents, especially calorie intake. That is because the effort to lose weight is an effort that synergizes variables with each other. It is not only related to the settings of food intake and physical activity but also an effort to start a healthier lifestyle.

Obese adolescents need to learn how to implement a better daily diet as directed through nutrition education with booklet media in this study. The Diet Approach to Stop Hypertension (DASH) in the nutrition education booklet has been shown to have benefits and recommended as a diet applied to obese adolescents. Early adolescence is not only a critical time to start and improve many risk behaviors but it can also provide important opportunities for health promotion through nutrition education. In the future, the application of booklets that contain daily diet advice in term of nutrition education can be a solution for the continuation of effective nutrition education for adolescents as the nutritional information about healthy daily (DASH) diet is easier to be comprehended and adapted into booklet recipient targets, and used in everyday life.

\section{ACKNOWLEDGEMENT}

The researchers would like to thank the high school adolescents in the city of Surakarta, the Department of Education and Culture of the Education Authorities in the Region VII Branch, the principals, and teachers of the State High School of the Surakarta City who were willing to participate in the implementation of this research.

\section{REFERENCES}

1. Hruby A, Hu FB. The Epidemiology of Obesity: A Big Picture. Pharmacoeconomics, 2016;33(7):673-89. https://doi.org/ 10.1007/s40273-014-0243-x PMCid:PMC4859313

PMid:25471927

2. Afshin A, Forouzanfar MH, Reitsma MB, Sur P, Estep K, Lee A, et al. Health effects of overweight and obesity in 195 countries over 25 years. New England Journal of Medicine, 2017;377(1):13-27. https://doi.org/10.1056/NEJMoa16 14362 PMid:28604169 PMCid:PMC5477817

3. Bhurosy $T$, Jeewon R. Overweight and obesity epidemic in developing countries: A problem with diet, physical activity, or socioeconomic status? Scientific World Journal, 2014. https://doi.org/10.1155/2014/964236 PMid:25379554 PMCid:PMC4212551

4. Lobstein T, Baur L, Uauy R. Obesity in children and young people: a crisis in. Obesity Reviews: An Official Journal of the International Association for the Study of Obesity, 2004;5:4-85. https://doi.org/10.1111/j.1467-789X.2004.001 33.x PMid:15096099

5. WHO. Consideration of the evidence on childhood obesity for the Commission on Ending Childhood Obesity: Report of the Ad hoc Working Group on Science and Evidence for Ending Childhood Obesity. In World Health Organization. 2016. Available at: https://apps.who.int/iris/bitstream/ handle/10665/206549/9789241565332_eng.pdf

6. Balitbangkes RI. Riset Kesehatan Dasar (RISKESDAS) 2010 [Basic Health Research Republic of Indonesia 2010]. 2010. Available at: http://labdata.litbang.depkes.go.id/riset-ba dan-litbangkes/menu-riskesnas/menu-riskesdas/148-rkd2010

7. Balitbangkes RI. Riset Kesehatan Dasar (RISKESDAS) 2013 [Basic Health Research Republic of Indonesia 2013]. 2013. Available at: http://labdata.litbang.depkes.go.id/riset-ba dan-litbangkes/menu-riskesnas/menu-riskesdas/374-rkd2013

8. Balitbangkes RI. Riset Kesehatan Dasar (RISKESDAS) 2018 [Basic Health Research Republic of Indonesia 2018]. 2018. Available at: http://labdata.litbang.depkes.go.id/riset-ba dan-litbangkes/menu-riskesnas/menu-riskesdas/426-rkd2018

9. Reicks M, Banna J, Cluskey M, Gunther C, Hongu N, Richards $\mathrm{R}$, et al. Influence of parenting practices on eating behaviors of early adolescents during independent eating occasions: Implications for obesity prevention. Nutrients, 2015;7(10):8783-801. https://doi.org/10.3390/nu7105431 PMid:26506384 PMCid:PMC4632451

10. Ogden CL, Carroll MD, Kit BK, Flegal KM. Prevalence of childhood and adult obesity in the United States, 20112012. JAMA - Journal of the American Medical Association, 2014;311(8):806-14. https://doi.org/10.1001/jama.2014.732 PMid:24570244 PMCid:PMC4770258

11. Venn AJ, Thomson RJ, Schmidt MD, Cleland VJ, Curry BA, Gennat HC, Dwyer T. Overweight and obesity from childhood to adulthood: A follow-up of participants in the 1985 Australian Schools Health and Fitness Survey. Medical Journal of Australia, 2007;186(9):458-60. https://doi.org/ 10.5694/j.1326-5377.2007.tb00997.x PMid:17484707 
12. Boyer BP, Nelson JA, Holub SC. Childhood body mass index trajectories predicting cardiovascular risk in adolescence. Journal of Adolescent Health, 2015;56(6):599-605. https://doi.org/10.1016/j.jadohealth.2015.01.006 PMid:25746172 PMCid:PMC4442729

13. Franks PW, Hanson RL, Knowler WC, Sievers ML, Bennett $\mathrm{PH}$, Looker HC. Childhood obesity, other cardiovascular risk factors, and premature death. The New England Journal of Medicine, 2010;362(6):485-93. https://doi.org/10.1056/NEJMoa0904130 PMid:20147714 PMCid:PMC2958822

14. Gupta-Malhotra M, Shete S, Barratt MS, Milewicz D, Syed, Hashmi S. Epidemiology of Childhood Onset Essential Hypertension. Journal of Human Hypertension, 2018:1-6. https://doi.org/10.1038/s41371-018-0110-x PMid:30224771 PMCid:PMC6265061

15. Anyaegbu El, Dharnidharka VR. Hypertension in the teenager. Pediatric Clinics of North America, 2014;61(1):131-51. https://doi.org/10.1016/j.pcl.2013.09. 011 PMid:24267462 PMCid:PMC3947917

16. Brady TM, Solomon BS, Neu AM, Siberry GK, Parekh RS. Patient-, Provider-, and Clinic-Level Predictors of Unrecognized Elevated Blood Pressure in Children. Pediatrics, 2010;125(6):e1286-e1293. https://doi.org/ 10.1542/peds.2009-0555 PMid:20439598

17. Bhupathiraju SN, Hu FB. Epidemiology of obesity and diabetes and their cardiovascular complications. Circulation Research, 2016;118(11):1723-35. https://doi.org /10.1161/CIRCRESAHA.115.306825 PMid:27230638 PMCid:PMC4887150

18. Soekarjo DD, Roshita A, Thow A-M, Li M, Rah JH. Strengthening Nutrition-Specific Policies for Adolescents in Indonesia: A Qualitative Policy Analysis. Food and Nutrition Bulletin, 2018:1-12. https://doi.org/10.1177/ 0379572118785054 PMid:30099923

19. Hill JO, Wyatt HR, Peters JC. Energy balance and obesity. Circulation, 2012;126(1):126-32. https://doi.org/10.1161/ CIRCULATIONAHA.111.087213 PMCid:PMC3401553

20. Kar SS, Dube R, Kar SS. Childhood obesity an insight into preventive. Avicenna Journal of Medicine, 2014;4(4):88-93. https://doi.org/10.4103/2231-0770.140653 PMid:25298951 PMCid:PMC4183902

21. Blumenthal JA, Babyak MA, Hinderliter A, Watkins LL, Craighead L, Lin P, et al. Effects of the DASH Diet Alone and in Combination With Exercise and Weight Loss on Blood Pressure and Cardiovascular Biomarkers in Men and Women With High Blood Pressure. Archive of Internal Medicine, 2010;170(2):126-35. https://doi.org/10.1001/ archinternmed.2009.470

PMid:20101007 PMCid:PMC3633078

22. Peairs AD, Shah AS, Summer S, Hess M, Couch SC. Effects of the dietary approaches to stop hypertension (DASH) diet on glucose variability in youth with Type 1 diabetes. Diabetes Management (London, England), 2017;7(5):383-91. Available at: http://www.ncbi.nlm.nih.gov/pubmed/ 29333199\%0A http://www.pubmedcentral.nih.gov/ articlerender.fcgi?artid=PMC5763547
23. Corsino L, Sotres-Alvarez D, Butera NM, Siega-Riz AM, Palacios C, Pérez CM, et al. Association of the DASH dietary pattern with insulin resistance and diabetes in US Hispanic/Latino adults: results from the Hispanic Community Health Study/Study of Latinos (HCHS/SOL). BMJ Open Diabetes Research \& Care, 2017;5(1):1-9. https://doi.org/10.1136/bmjdrc-2017-000402 PMid:28761660 PMCid:PMC5530245

24. Esfandiari S, Bahadoran Z, Mirmiran P, Tohidi M, Azizi F. Adherence to the dietary approaches to stop hypertension trial (DASH) diet is inversely associated with incidence of insulin resistance in adults: The Tehran lipid and glucose study. Journal of Clinical Biochemistry and Nutrition, 2017;61(2):123-9. https://doi.org/10.3164/jcbn.16-95 PMid:28955129 PMCid:PMC5612815

25. Asnidar A. Pendidikan Kesehatan Berbasis Media Sosial Untuk Mengubah Pengetahuan, Gaya Hidup Dan Indeks Massa Tubuh Remaja Obesitas Di Bulukumba [Social Media Based Health Education to Change Knowledge, Lifestyle and Body Mass Index of Adolescent Obesity in Bulukumba]. Universitas Hasanudin Makasar. 2017.

26. Lanita U, Sudargo T, Huriyati E. Pengaruh pendidikan kesehatan melalui short message service (sms) dan booklet tentang obesitas pada remaja overweight dan obesitas [The effect of health education by short message service (sms) and booklet about obesity in overweight and obese adolescent]. Jurnal Gizi Klinik Indonesia, 2015;12(1):36-44. https://doi.org/10.22146/ijcn.22920

27. NHLBI. National Institute of Health. National Heart, Lung and Blood Institute. Your guide to lowering your blood pressure with DASH. 2006. https://doi.org/ 10.1037/e566492010-001

28. Kowalski KC, Crocker PR, Donen RM. Physical Activity Questionnaire for Older Children (PAQ-C) and Adolescents (PAQ-A). Saskatoon: University of Saskatchewan. 2004. Available at: https://www.performwell.org/index.php/findsurveyassessments/outcomes/health-a-safety/goodhealth-habits/physical-activity-questionnaire-for-children

29. Mazloomy-Mahmoodabad SS, Navabi ZS, Ahmadi A, Askarishahi M. The effect of educational intervention on weight loss in adolescents with overweight and obesity: Application of the theory of planned behavior. ARYA Atherosclerosis, 2017;13(4):176-83.

30. Bleich SN, Bandara S, Bennett W, Cooper LA, Gudzune KA, Medical JH. Enhancing the role of nutrition professionals in weight management: A cross sectional survey. Obesity (Silver Spring), 2015;23(2):454-60. https://doi.org/10.1002/ oby.20945 PMid:25445319 PMCid:PMC4310773

31. Spolidoro JV, Pitrez Filho ML, Vargas LT, Santana JC, Pitrez E, Hauschild JA, et al. Waist circumference in children and adolescents correlate with metabolic syndrome and fat deposits in young adults. Clinical Nutrition,2013;32(1):93-7. https://doi.org/10.1016/j.clnu.2012.05.020 PMid:22841400

32. Lee S, Bacha F, Gungor N, Arslanian SA. Waist circumference is an independent predictor of insulin resistance in black and white youths. Journal of Pediatrics, 2006;148(2):188-94. https://doi.org/10.1016/j.jpeds.2005. 10.001 PMid:16492427

33. Motlagh ME, Shirvani S, Hassanzadeh-Rostami Z, Taheri M, Ghadimi R. Assessment of overweight and obesity in Iranian adolescents: Optimal cut-off values of anthropometric indices. Eastern Mediterranean Health Journal, 2018;24(10):975-87. https://doi.org/10.26719/ 2018.24.10.975 PMid:30582140 
34. Siren R, Eriksson JG, Vanhanen H. Waist circumference a good indicator of future risk for type 2 diabetes and cardiovascular disease. BMC Public Health, 2012;12(1). https://doi.org/10.1186/1471-2458-12-631 PMid:22877354 PMCid:PMC3490795

35. Asma PN, John S, Monica SJ. Dietary pattern and nutrient intake of overweight and normal weight adolescent girls - A cross-sectional study. Asian Journal of Pharmaceutical and Clinical Research, 2018;11(1):264-7. https://doi.org/ 10.22159/ajpcr.2018.v11i1.22178

36. Dharmade PN, Kale MP. Effect of nutrition education on anthropometric measurements of adolescent girls. International Journal of Home Science, 2017;3(1):136-40. Available at: http://www.homesciencejournal.com/ archives/2017/vol3issue1/PartC/3-1-9.pdf

37. Jaiswal M, Bansal R, Agarwal A. Role of mid-upper arm circumference for determining overweight and obesity in children and adolescents. Journal of Clinical and Diagnostic Research, 2017;11(8):SC05-SC08. https://doi.org/10.7860/JCDR/2017/27442.10422 PMid:28969228 PMCid:PMC5620869

38. Pandita A, Sharma D, Pandita D, Pawar S, Tariq M, Kaul A. Childhood obesity: Prevention is better than cure. Diabetes, Metabolic Syndrome and Obesity: Targets and Therapy, 2016;9:83-9. https://doi.org/10.2147/ DMSO.S90783 PMid:27042133 PMCid:PMC4801195
39. Esler M. The 2009 Carl Ludwig Lecture: pathophysiology of the human sympathetic nervous system in cardiovascular diseases: the transition from mechanisms to medical management. Journal of Applied Physiology, 2010;108(2):227-37. https://doi.org/10.1152/japplphysiol. 00832.2009 PMid:19940096

40. Straznicky NE, Grima MT, Eikelis N, Nestel PJ, Dawood T, Schlaich MP, et al. The effects of weight loss versus weight loss maintenance on sympathetic nervous system activity and metabolic syndrome components. Journal of Clinical Endocrinology and Metabolism, 2011;96(3):503-8. https://doi.org/10.1210/jc.2010-2204 PMid:21177786

41. Juncos LI. Salt intake in childhood and adolescence. Hypertension, 2014;63(5):911-2. https://doi.org/10.1161/ HYPERTENSIONAHA.113.02660 PMid:24614219

42. Ewald DR, Haldeman LA. Risk Factors in Adolescent Hypertension. Global Pediatric Health, 2016;3:1-26. https://doi.org/10.1177/2333794X15625159 PMid:27335997 PMCid:PMC4784559

43. De La Haye K, D’Amico EJ, Miles JNV, Ewing B, Tucker JS. Covariance among multiple health risk behaviors in adolescents. PLOS ONE, 2014;9(5):1-5. https://doi.org/ 10.1371/journal.pone.0098141 PMCid:PMC4032285
PMid:24858838 